\section{THE GOPHER}

by Herbert Mimrichter, Age 11, Barthel, Sask.

The gopher dug his little hole Right beside the telephone pole He dug and dug with his little claws They are much smaller than a bear's or a dog's.

I tried to catch him but I could not He ran so fast-I'm sure he was hot, It took him a while to dig his hole, Why he almost dug out that telephone pole!

He has nice matching colors-yellow and black,

And little dark stripes upon his back, Then in his hole he was at last

I watched this fellow until the day passed.

Oh! When in the morning-guess what I found?

Not a thing but many holes in the ground,

Where had he gone? This little friend

Could he still be digging, digging, without end?

NOTE: The "thing" in the following poem turns out to be a salamander. Persons interested in salamanders and lizards should obtain the following publication now available upon requqest: "Check-list of the Amphibians and Reptiles of Canada and Alaska" by E. B. S. Logier and G. C. Toner, 1955, Contributions of the Royal Ontario Museum of Zoology and Palezntology No. 41.

\section{THE THING}

By Edward Hennon, age 10, Goodwater, Sask.-Prize winner

I was digging one morning

I think in July

When I dug up a lizard And, "Oh my!" said I.

What is this thing

With the great big head?

I really was scared

And I had to dread

The thought of holding it Near my head.

So I hit it a good one With the stick I was holding The lizard went squirming And a little bit rolling.

I went to the house

To ask what it was

And when I came back It was, it was,

A little old salamander With a great big head, And a few little beatings And then it was dead.

I shouldn't have done it, I know now it was bad, To kill just a lizard, My gosh what a lad I was.

\title{
CROW OBSERVATIONS
}

By James Liggett, age 10,

Moreland, Sask.-Prize winner

One day last summer my friend and I spent the afternoon at a small grove of trees about a quarter of a mile from cur house.

The plan for the afternoon was to climb a tree and see if there were eggs in the crow's nest. After trying for some time we resolved to climb a neighboring tree and then swing back to the tree where the nest was. After reaching the tree we were confronted with the problem of getting past a thick growth of branches. Finally, bruised and scratched, I reached the nest.

In the nest there was a newly hatched bird and four eggs. Y watched them and then went hom For weeks we watched the bird First the birds got their pluma which was rather scraggly, and the they got their eyes open. Final three weeks after the crows we: hatched, I went over one night ar found the birds flying, all exce the oldest one-he had a deforms leg.

I took him home where we $p$ him in with a lame chicken name Charlie. The crow was never real named, but we just fell in wi Blackie. His staple food was brea 
d milk, and he showed a dislike eggs. When he began flying he d the rule of the yard.

Ho would tease the cats, eat the icken's feed and scare them, and hen Dad milked he would sit on the ws' necks.

One day we built a tin tray where placed his food. When the ickens tcok his food, he ruffed his feathers and flew-cawing ter the chickens, although he sharhis food with the sparrows.

When strangers came he would fly them and their car and because is never succeeded in scaring them, flew away and stayed out of ght until they left.

In August, his mother came and ied to persuade him to go away cm humans, but he solemnly reused. Then one night he got locked with the chickens and got squeezd and ruffed up. I've never seen a ird show his feelings or converse plainly as he did.

Shortly after this accident he left, lthough he visited us regularly. efore he went scuth he came back nd cawed until Mom went ou' and hen he circled around the pole and ft. I'm sure he'll come back in the pring.

\section{STRIPED SQUIRREL}

y Bonnie Frew, age 15, Pense, Sask. My personal experienze with wild fe was with a striped squirrel more ommonly known as a striped goher. Although these animals are estructive they can sometimes be amed with a lot of patience.

M.y first experience with a striped opher happened at my aunt's. She ad several striped gophers on hər lace. One became so used to me hat he wculd not even run; that is, I did not frighten him by a sudden nove. One day I decided to try an xperiment. I put a marshmallow on long stick and held it out to the triped gopher. At first the stripcd opher was very cautious but then le began to nibble at the marshmalcw and then finally to eat it. I did ot have any more experiences with his particular striped gopher because had to leave for home the next day.

A few years later on our farm we iad another striped gopher that got oo tame as far as the chickens were oncerned. One day our pet red ooster took after the striped gopher and chased him to the gopher hole. It was really funny looking at the rooster with his neck stuck down the gopher hole trying to get the gopher and the way that rooster strutted across the yard when it found out it could not get the striped gopher.

So you see, you can have fun with wild life even though they are supposed to be so destructive.

\section{TWO DETERMINED TREE SWALLOWS}

By Janice Bradshaw, age 11,
Saltccats, Sask.

Last spring we noticed two tree swallows sitting on the muffler of the little tractor which stood near the barn. My dad didn't use this tractor very often because he had a larger one. One day he wanted to gc harrowing so he started the little tractor and out of the muffler flew iwigs and grass. The tree swallows had started to make their nest in the muffler.

Just as my dad finished harrowing, the traztor ran out of gas so he walked home, leaving the tractor in the field abcut three quarters of a mile away. About three days later when he went for the tractor, twigs and grass flew out of the muffler again when he started it. He then noticed the swallows around. They must have followed the tractor out to the field.

When the tractor was back in the yard, we noticed the swallows began their work of building their nest in the muffler again. They were so determined to make their home in the muffler that my dad tcok off the muffler and placed it on the combine nearby. The nest was soon completed and eggs laid in it.

For the rest of the spring season the tractor was used without the muffler.

\section{AN ADVENTURE WITH A GARTER SNAKE}

by Ed Andres, age 9, Rosthern, Sask

One time in a town close to Swift Current a friend of mine and myself found some garter snakes. We played with them for a while. I had one in my hand. My friend put the snake he had around his neck. After we played with them we put them where we found them. They were very friendly. 